\title{
BIOLOGICAL CONTROL OF Fusarium culmorum ISOLATED FROM THE CULTIVATION OF WHITE ASPARAGUS BY Pseudomonas fluorescens
}

\section{BIOLOGICZNA KONTROLA Fusarium culmorum WYYIZOLOWANEGO Z UPRAWY BIELONEGO SZPARAGA PRZEZ Pseudomonas fluorescens}

\author{
Department of Biotechnology and Molecular Biology, Opole University, Poland
}

\begin{abstract}
Streszczenie. Celem badań była ocena wpływu Pseudomonas fluorescens I-4 (Ps I-4) na Fusarium culmorum wyizolowanego z uprawy białego szparaga. Fusarium culmorum i pozostałe grzyby izolowano na podłożach PDA i szparagowym. Wśród izolatów uzyskanych z gleby najbardziej dominującymi patogenami były $F$. oxysporum i $F$. culmorum. Właściwości biologiczne nielotnych i lotnych związków Ps I-4 oceniano metodą hodowlano-płytkową na podłożach PDA i Czapka. Aktywność przeciwgrzybową określano na podstawie indeksu tempa wzrostu, zdolności kiełkowania zarodników, stopnia zahamowania wzrostu grzybni i zarodników. Wyniki wykazały różnice w aktywności przeciwgrzybowej $P$. fluorescens, w zależności od wieku i gęstości hodowli bakteryjnej, rodzaju pożywki i obecności lotnych lub nielotnych metabolitów. Ps I-4 wykazał wyższą aktywność na zdolność kiełkowania zarodników grzybów (82-94\% zahamowania) niż w przypadku wzrostu grzybni $F$. culmorum. Największe hamowanie liniowego wzrostu grzybni było obserwowane po zastosowaniu supernatantów otrzymanych z 6-godzinnej hodowli (zahamowanie 64-76\%). P. fluorescens I-4 wykazał również zdolność syntezy metabolitów: HCN, sideroforów, proteaz, lipaz i solubilizacji fosforanu.
\end{abstract}

Key words: Fusarium culmorum, antifungal activity, Pseudomonas fluorescens, Asparagus officinalis $\mathrm{L}$.

Słowa kluczowe: Fusarium culmorum, aktywność przeciwgrzybowa, Pseudomonas fluorescens, Asparagus officinalis L.

\section{INTRODUCTION}

White asparagus (Asparagus officinalis L.) is eaten worldwide due to its high nutritional values and presence of biotic compounds (Weber et al. 2007; Cieślik and Siembida 2011). However, asparagus can be attacked by different phytopathogens. Among the more important fungal diseases there are purple spot, gray mould, asparagus rust, fusarium crown, root and stem rot, that cause severe losses in its production. These symptoms are caused by Stemphylium sp., Botrytis cinerea, Puccinia asparagi, Fusarium sp. (Blok and Bollen 1995; Kalomira 2007; Elmer 2010). The intensification of fungal occurrence depends primarily on the asparagus cultivar susceptibility, environmental conditions and agricultural practices (Weber et al. 2007; Koralewski et al. 2011). The long-lasting nature of asparagus cultivation with the production cycle of up to 15 years or more, and the lack of ability to introduce crop rotation 
cause the accumulation of pests in the soil for which asparagus is the host. Among of Fusarium genus, F. oxysporum, F. solani, F. proliferatum and F. culmorum are known as the main pathogens of asparagus cultivar. These fungus survives in the soil indefinitely, and may spread as a seed-borne and crown contaminant (Weber et al. 2007; Molinero-Ruiz et al. 2011; Nahiyan et al 2011; Łabanowski et al. 2016). Control of Fusarium crown and root rot has been difficult since the pathogens are ubiquitous and appear to be present in most field soils (Elmer 2010; Elmer 2015).

Many different approaches have been used to manage the diseases of asparagus. In recent years there has been increased interest in the possibility of using natural antagonists such as Pseudomonas spp. and Burkholderia spp. (formerly included in Pseudomonas) as biological agents of plant protection and plant disease control (Ligon et al. 2000; Nabrdalik and Grata 2014; Grata 2016). Several mechanisms have been indicated as responsible for their antagonistic activity, including secretion of bioactive compounds, competition for space and nutrients, promoting plant growth and inducing systemic resistance (ISR). Pseudomonas fluorescens comprise a large group of active biocontrol strains as a result of their ability to produce a diverse array of potent antifungal diffusible or volatile extracellular metabolites. These include metabolites such Phenazine-1-Carboxylic Acid (PCA), 2, 4 - Diacetylphloroglucinol (DAPG), Pyocyanine, Pyrrolnitrin, Pyoluteorin (PLT) which are fungistatic and capable of inhibiting a number of serious plant pathogens (Lejbølle 2004; Weller 2007; Koche et al. 2013). In many cases the production of these compounds has been directly correlated with biocontrol activity. Some species of Pseudomonas can also produce siderophores (iron-sequestering compounds), HCN, phosphate solubilizing enzymes, lytic enzymes that are toxic to certain pathogenic fungi (Ligon et al. 2000; Mahalakshimi and Reetha 2009; Jankiewicz 2010; Ramyasmruthi et al. 2012; Jankiewicz et al. 2013; Mnif and Ghribi 2015). These features allow to consider Psudomonas fluorescens as a potential and effective agent in biological plant protection. The aim of this study was to assess the suppressing effect of Psudomonas fluorescens on the mycelium growth and spore germination of Fusarium culmorum isolated from the cultivation of white asparagus (Asparagus officinalis L.)

\section{MATERIAL AND METHODS}

Fusarium culmorum isolated from the cultivation of white asparagus and the strain of Pseudomonas fluorescens was used as material for this study. Firstly, the following indicators were used for the soil mycological characterization: aggregate density index ( $\mathrm{Ag}$ - cfu/g), percentage of individual types/species of fungi (U), Simpson's diversity index (I) (Trojan 1992). Isolation of the fungus was performed on the PDA and asparagus media incubated at $23 \mathrm{C} \pm 2^{\circ} \mathrm{C}$ for 5-7 days. Based on the diagnostic keys, identification of isolated fungi was performed (Domsh et al. 1980; Pitt and Hocking 1985; Leslie and Brett 2006).

\section{Detection of secondary metabolites}

Protease and lipase production was assayed by using skim milk agar and tributyrin agar, respectively. Phosphatase activity (containing tricalcium phosphate) was detected in Pikovskaya's agar medium. This activity was determined by the development of a clear zone in this media. Production of $\mathrm{HCN}$ was determined on the TSA medium supplemented with 
glycine. Discoloration of the filter paper disc impregnated with a solution of picric acid and sodium carbonate from yellow to brown or reddish brown after incubation (for $2-4$ days at $30^{\circ} \mathrm{C}$ ) indicated the production of HCN (Kumar et al. 2005; Vanitha and Ramjegathesh 2014).

\section{Detection of antifungal activity}

The $P$. fluorescens strain, encoded as Ps I-4, was cultured in the broth medium on a rotary shaker at $100 \mathrm{rpm}$ for $48 \mathrm{~h}$ at $30^{\circ} \mathrm{C}$. Next, the nutrient broth was inoculated with bacterial cultures at a density of $\mathrm{OD}_{560}=1.0\left(4.11 \cdot 10^{8} \mathrm{cfu} \cdot \mathrm{ml}^{-3}\right)$ and $\mathrm{OD}_{560}=2.0\left(8.22 \cdot 10^{8} \mathrm{cfu} \cdot \mathrm{ml}^{-3}\right)$. These cultures were incubated at $30^{\circ} \mathrm{C}$ for different lengths of time $-6,12,24$ and 48-hour cultures. After each period of time, the cultures were centrifuged at $10000 \mathrm{rpm}$ for $15 \mathrm{~min}$ at $4^{\circ} \mathrm{C}$. The cell-free supernatants (CFs) containing the metabolite and the crude enzyme were analysed in order to estimate the degree of antifungal activities. The F. culmorum strain was cultivated on a PDA medium at $25^{\circ} \mathrm{C}$ for 7 days.

The antifungal effect of the tested strain (in both non-volatile and volatile compounds) was observed by employing various antifungal assays. The fungistatic activity of non -volatile compounds of $P$. fluorescens I-4 was determined using the culture-plate method on the PDA and Czapek media. The supernatants were spread thoroughly all over the surface of all plates. Fungal mycelial-discs $(7.0 \mathrm{~mm}$ in diameter) obtained from the growing cultures of the test fungal isolate were placed at the centre of the medium inoculated with the supernatants. The volatile compound produced by the Ps I-4 strain was determined by the inverted plate technique (Dennis and Webster 1971). Petri dishes containing the PDA and Czapek media were inoculated at the centre with mycelial disc ( $7 \mathrm{~mm}$ in diameter). In contrast, each of the supernatants was spread over the surface of the TSA medium. The plates (PDA or Czapek media and TSA) were hermetically sealed with parafilm to prevent the leakage of volatile fractions. The control plates contained only F. culmorum cultures. All plates were incubated in the dark at $23^{\circ} \mathrm{C} \pm 2^{\circ} \mathrm{C}$ for 7 days until the growth in the control plates reached their edges. The radial mycelia growth was observed and measured at two perpendicular diameters at 1-2 day intervals.

The antagonistic activity of the PS I-4 strain was evaluated as the growth rate index and additionally expressed as the percentage of mycelial growth inhibition in comparison to the control (Burgieł 1984). The evaluation of fungistatic activity of Ps I-4 was also carried out on the basis of spore germination of $F$. culmorum. The conidia of this fungus were harvested from the 5-day-old culture grown in the PDA medium and then conidia suspensions were filtered through the sterile gauze and adjusted to the concentration of $2.55 \cdot 10^{6}$ spores $\cdot \mathrm{ml}^{-3}$ using the Thoma haemocytometer. Subsequently, aliquots of $40 \mu \mathrm{l}$ of the supernatants were mixed with $40 \mu \mathrm{l}$ of the spores suspension in the microscopic slide. Then they were incubated in a moist chamber at $23^{\circ} \mathrm{C} \pm 2^{\circ} \mathrm{C}$ for $18 \mathrm{~h}$. The spores, germinated and non-germinated in varying degrees, were enumerated and evaluated by microscopic observation. The data was presented as the rate of conidia germination and the percentage of spore germination inhibition (Burgieł 1989). All experiments were conducted in four replications. The data is expressed as the mean \pm standard deviation. Statistical analyses were performed using two-way analysis of variance with a Tukey's composition test (MegaStat add-in for Excel). Significant differences were determined with $99 \%$ confidence intervals ( $p \leq 0.01$ ). 


\section{RESULTS AND DISCUSSION}

Several pathogenic Fusarium species occurred in the soil, crown and spears of asparagus. The genus Fusarium contains a number of species, which have been recognised as an important plant pathogen. Fusarium culmorum is known as the cause of foot and stem rot (Kalomira 2007; Weber et al. 2007). Therefore, there is a need to search for natural antagonists among the bacteria such as Pseudomonas sp. and Bacillus sp. that limit the growth and development of the pathogenic fungus.

The research shows that the highest population of the fungi was detected on the asparagus medium. The number of colony-forming units $(\mathrm{Ag})$ was about $20.0 \%$ higher than on the PDA medium. Among the obtained isolates the most numerous were those from the genus Fusarium and their number was from $12.5 \cdot 10^{3} \mathrm{cfu} \cdot \mathrm{g}$ on the PDA medium to $15.5 \cdot 10^{3} \mathrm{cfu} \cdot \mathrm{g}$ on the asparagus one. The other isolated species belonged to the genera Penicillium, Trichoderma, Cladosporium. The fungi from the genus Fusarium belonged to 5 species, but $F$. oxysporum and $F$. culmorum were the dominant pathogen. In addition, the higher diversity of fungal isolates was found on the PDA medium $(I=0.89)$ compared to the asparagus medium $(I=0.83)-$ Table 1.

Table 1. Mycological characteristics of the soil Tabela 1. Charakterystyka mikologiczna gleby

\begin{tabular}{|c|c|c|c|c|c|c|}
\hline \multirow{3}{*}{$\begin{array}{l}\text { Species } \\
\text { Rodzaj }\end{array}$} & \multicolumn{6}{|c|}{$\begin{array}{c}\text { Type of media } \\
\text { Rodzaj pożywki }\end{array}$} \\
\hline & \multicolumn{3}{|c|}{$\begin{array}{l}\text { PDA medium } \\
\text { pożywka PDA }\end{array}$} & \multicolumn{3}{|c|}{$\begin{array}{l}\text { asparagus medium } \\
\text { pożywka szparagowa }\end{array}$} \\
\hline & $\begin{array}{c}\mathrm{Ag} \\
{\left[\mathrm{CFU} \cdot 10^{3} \cdot \mathrm{g}\right]} \\
{\left[\text { jtk } 10^{3} \cdot \mathrm{g}\right]}\end{array}$ & $\begin{array}{c}U \\
{[\%]}\end{array}$ & $\begin{array}{c}1 \\
{[\%]}\end{array}$ & $\begin{array}{c}\mathrm{Ag} \\
{\left[\mathrm{CFU} \cdot 10^{3} \cdot \mathrm{g}\right]} \\
{\left[\text { jtk } 10^{3} \cdot \mathrm{g}\right]}\end{array}$ & $\begin{array}{c}\cup \\
{[\%]}\end{array}$ & $\begin{array}{c}1 \\
{[\%]}\end{array}$ \\
\hline Fusarium sp.: & 6.5 & 52.0 & & 10.0 & 64.52 & \\
\hline F. oxysporum & 3.0 & 24.0 & & 4.0 & 25.81 & \\
\hline F. culmorum & 1.5 & 12.0 & & 1.0 & 6.46 & \\
\hline F. solani & 1.0 & 8.0 & & 3.0 & 19.35 & \\
\hline F. proliferatum & 0.5 & 4.0 & & nd. & nd. & \\
\hline F. trictinum & 0.5 & 4.0 & & 2.0 & 12.9 & \\
\hline Penicillium sp.: & 1.5 & 12.0 & & nd. & nd. & \\
\hline P. expansum & 0.5 & 4.0 & & nd. & nd. & \\
\hline P. cyclopium & 1.0 & 8.0 & & nd. & nd. & \\
\hline Trichoderma sp: & 2.5 & 20.0 & & 1.5 & 9.68 & \\
\hline T. koningii & 1.5 & 12.0 & & 1.0 & 6.45 & \\
\hline T. viride & 1.0 & 8.0 & & 0.5 & 3.22 & \\
\hline Cladosporium sp. & 1.0 & 8.0 & & nd. & nd. & \\
\hline Scopularopsis sp. & 0.5 & 4.0 & & 2.5 & 16.13 & \\
\hline Mucor sp. & 0.5 & 4.0 & & nd. & nd. & \\
\hline Rhizopus sp. & nd. & nd. & & 1.5 & 9.67 & \\
\hline Sum - Suma & 12.5 & 100 & 0.89 & 15.5 & 100 & 0.83 \\
\hline
\end{tabular}

nd. - not detected - nie wyizolowano.

Andrzejak (2012) showed in their research, that apart from F. oxysporum the species isolated most frequently include F. culmorum and F. proliferatum. Similarly, another authors observed, that $F$. oxysporum was most frequently isolated, while $F$. culmorum occurred only occasionally (Weber et al. 2007; Nahiyan et al. 2011; Elmer 2015). 
The research shows that $P$. fluorescens $1-4$ density, the incubation period and the kind of medium had a significant impact on the growth of mycelium and the degree of inhibition. The antagonistic effect of the non-volatile and volatile compounds produced by the Ps I-4 strain was evaluated on the 2 media (PDA and Czapek media). In these tests, it was observed that in the presence of supernatants the mycelium grew slower and was morphologically altered compared to the mycelium in the control tests. Statistical differences were found $(p \leq 0.01)$ between the control and other supernatants. The strongest antifungal activity of all supernatants on both media against $F$. culmorum was observed in case of the 6-hour culture of Ps I-4. The growth rate index amounted from 25.35 to 26.69 on the PDA medium and from 25.98 to 27.15 on the Czapek medium. These results were 4-fold lower than those observed in the control trials. On the other hand, a 24-hour culture on the PDA medium and a 48-hour culture on the Czapek one showed the weakest effect of Ps I-4 on mycelium growth. These results were 2- to 3-fold lower than those observed in the control plates (Table 2).

Table 2. Influence of supernatants of Pseudomonas fluorescens I-1 on the linear growth of Fusarium culmorum

Tabela 2. Wpływ supernatantów Pseudomonas fluorescens I-4 na wzrost Fusarium culmorum

\begin{tabular}{lcccc}
\hline \multirow{2}{*}{$\begin{array}{c}\text { Culturing time } \\
\text { Czas hodowli } \\
{[\mathrm{h}]}\end{array}$} & \multicolumn{4}{c}{$\begin{array}{c}\text { Type of media } \\
\text { Rodzaj pożywki }\end{array}$} \\
\cline { 2 - 5 } & OD 1.0 & OD 2.0 & OD 1.0 & Czapek \\
\cline { 2 - 5 } $\begin{array}{l}\text { Control } \\
\text { Kontrola }\end{array}$ & $103.21 \pm 0.31^{\mathrm{E}}$ & $103.21 \pm 0.31^{\mathrm{E}}$ & $102.65 \pm 0.31^{\mathrm{E}}$ & $102.65 \pm 0.31^{\mathrm{E}}$ \\
\hline 6 & $25.35 \pm 0.11^{\mathrm{A}}$ & $26.69 \pm 0.14^{\mathrm{A}}$ & $27.15 \pm 0.08^{\mathrm{A}}$ & $25.98 \pm 0.06^{\mathrm{A}}$ \\
\hline 12 & $37.09 \pm 0.12^{\mathrm{C}}$ & $31.39 \pm 0.11^{\mathrm{B}}$ & $28.39 \pm 0.07^{\mathrm{B}}$ & $29.92 \pm 0.04^{\mathrm{B}}$ \\
\hline 24 & $42.30 \pm 0.30^{\mathrm{D}}$ & $36.05 \pm 0.12^{\mathrm{D}}$ & $36.33 \pm 0.05^{\mathrm{C}}$ & $30.18 \pm 0.04^{\mathrm{C}}$ \\
\hline 48 & $27.14 \pm 0.14^{\mathrm{B}}$ & $35.78 \pm 0.12^{\mathrm{C}}$ & $37.28 \pm 0.06^{\mathrm{D}}$ & $33.53 \pm 0.03^{\mathrm{D}}$ \\
\hline
\end{tabular}

OD - optical density - gęstość optyczna.

The presented paper shows in most cases that prolonging the culturing time affects the inhibition rate of linear growth of mycelium. The highest inhibition of the growth of F. culmorum was noted in case of 6 -hour culturing of bacterium and amounted from $73.55 \%$ to $75.4 \%$ on the PDA medium and from $73.5 \%$ to $74.69 \%$ on the Czapek medium. However, a 24-hour culture on the PDA medium and a 48-hour culture on the Czapek medium showed a smaller impact (Fig. 1).

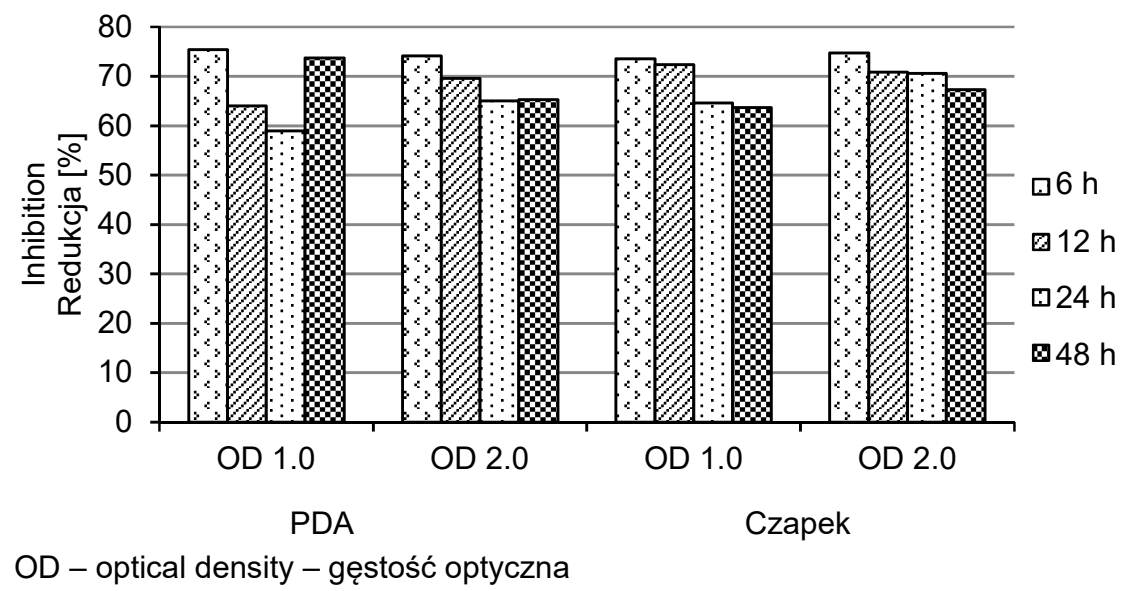

Fig. 1. Reduction of the growth of $F$. culmorum by supernatants of Pseudomonas fluorescens I-4 Ryc. 1. Zahamowanie wzrostu F. culmorum przez supernatanty Pseudomonas fluorescens I-4 
The results obtained by the inverted plate technique indicated, that also volatile metabolites limited significantly the mycelium growth of $F$. culmorum. The growth rate index was 1-2 times lower than that found in the control trials. The greatest inhibition of linear growth was found on the PDA medium after the application of a 24-hour and a 48-hour culture of Ps I-4, respectively for density of $O D=2.0$ and $O D=1.0$. In contrast, on the Czapek medium, an even better effect on the mycelial growth was noted for a 6-hour culture of Ps I-4, while the weakest for a 48-hour culture (Table 3).

Table 3. Influence of volatile metabolites of Pseudomonas fluorescens I-1 on the growth of Fusarium culmorum

Tabela 3. Wpływ gazowych metabolitów Pseudomonas fluorescens I-4 na wzrost Fusarium culmorum

\begin{tabular}{lcccc}
\hline \multirow{2}{*}{$\begin{array}{c}\text { Culturing time } \\
\text { Czas hodowli } \\
{[\mathrm{h}]}\end{array}$} & \multicolumn{4}{c}{$\begin{array}{c}\text { Type of media } \\
\text { Rodzaj pożywki }\end{array}$} \\
\cline { 2 - 5 } & OD 1.0 & OD 2.0 & OD 1.0 & OD 2.0 \\
\cline { 2 - 5 } $\begin{array}{l}\text { Control } \\
\text { Kontrola }\end{array}$ & $104.61 \pm 0.05^{\mathrm{E}}$ & $104.61 \pm 0.05^{\mathrm{E}}$ & $106.67 \pm 0.07^{\mathrm{E}}$ & $106.67 \pm 0.07^{\mathrm{E}}$ \\
\hline 6 & $61.11 \pm 0.09^{\mathrm{D}}$ & $66.43 \pm 0.05^{\mathrm{D}}$ & $29.38 \pm 0.07^{\mathrm{C}}$ & $21.60 \pm 0.06^{\mathrm{A}}$ \\
\hline 12 & $48.76 \pm 0.04^{\mathrm{A}}$ & $39.04 \pm 0.06^{\mathrm{A}}$ & $22.35 \pm 0.06^{\mathrm{A}}$ & $23.55 \pm 0.05^{\mathrm{B}}$ \\
\hline 24 & $50.36 \pm 0.06^{\mathrm{C}}$ & $45.43 \pm 0.05^{\mathrm{B}}$ & $29.17 \pm 0.06^{\mathrm{B}}$ & $26.30 \pm 0.04^{\mathrm{C}}$ \\
\hline 48 & $43.02 \pm 0.05^{\mathrm{B}}$ & $48.58 \pm 0.05^{\mathrm{C}}$ & $45.73 \pm 0.05^{\mathrm{D}}$ & $39.33 \pm 0.05^{\mathrm{D}}$ \\
\hline
\end{tabular}

OD - optical density - gęstość optyczna.

It was found, that the degree of inhibition of mycelium was higher on the Czapek medium than observed on the PDA medium. Therefore, the highest reduction of mycelium growth amounted from $58.87 \%$ to $62.68 \%$ (PDA medium) and $79.05 \%$ to $79.75 \%$ (Czapek medium) - Fig. 2.

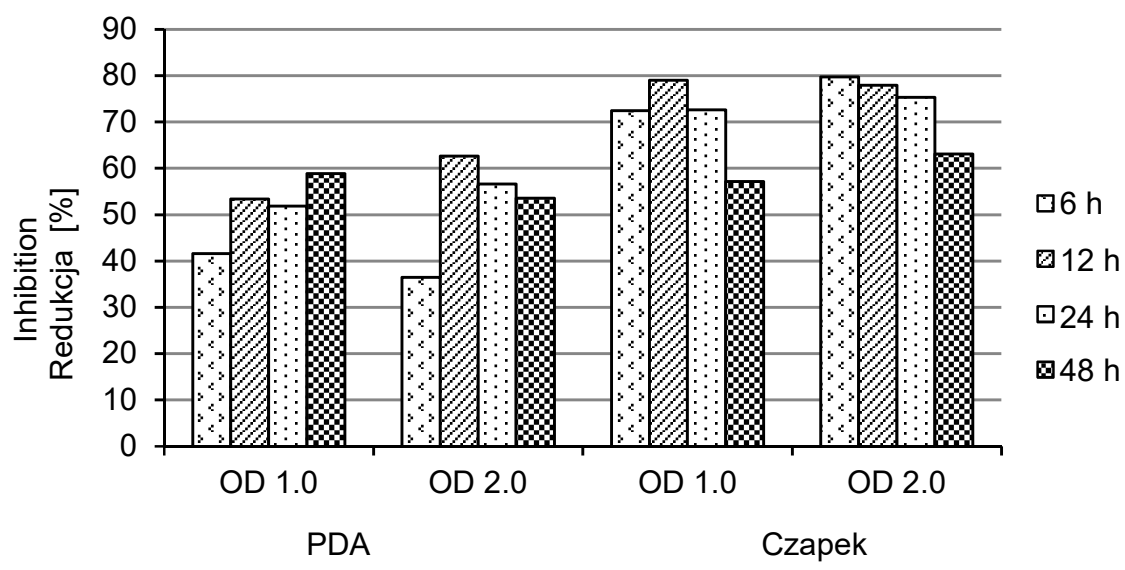

OD - optical density - gęstość optyczna

Fig. 2. Reduction of the growth of $F$. culmorum by volatile metabolites of Pseudomonas fluorescens I-4 Ryc. 2. Zahamowanie wzrostu F. culmorum przez metabolity gazowe Pseudomonas fluorescens I-4

The results obtained in this research are in agreement with the results of the other authors who showed in vitro suppression of the growth of the pathogenic fungi in interaction with bacteria of the genus Pseudomonas. Pandey ans Chandel 2014 tested the antagonistic activities of three Pseudomonas species against six fungi observed the inhibition in colony diameter from $64 \%$ to $89 \%$. Other studies carried out by Maurya et al. 2014 indicated, that 
three of $P$. fluorescens isolates significantly inhibited growth of the tested fungi. In case of $F$. moniliforme, $R$. solani and $A$. alternata the maximum inhibition amounted $65.45 \%, 68.23 \%$ and $48.13 \%$, respectively. Mahalaskhimi and Reetha 2009 prove, that twelve of Pseudomonas isolates; which produces $\mathrm{HCN}$, siderophores were efficient in inhibiting $F$. oxysporum and $R$. solani. These results are also consistent with reports of Vanitha and Ramjegathesh 2014 who reported antifungal activity of volatile metabolites secreted by 11 of $P$. fluorescens strains. The degree of inhibition of mycelium growth was dependent on the Pseudomonas strain and amounted to about $50-80 \%$, while in this research it was about $36-80 \%$. Koche et al. 2013 showed in their research the activity of secondary metabolites extracted from 12 P. fluorescens strains. The crude compound inhibited the growth of all pathogens at $5 \%$. The maximum growth inhibition was recorded in $R$. solani (42.79\%) but the least inhibition was observed in F. solani (20.45\%). Jankiewicz 2010 demonstrated that two isolates of $P$. fluorescens were most efficient in terms of mycelial growth inhibition of $F$. culmorum (80-85\% inhibition), F. oxysporum (80-90\% inhibition). Similar results were obtained in our study, because the degree of inhibition of mycelial growth of $F$. culmorum by $P$. fluorescens 14 ranged from $58.99 \%$ to $75.42 \%$ for non-volatile metabolites and from $36.49 \%$ to $79.75 \%$ for volatile ones. In contrast, supernatants showed a much greater impact on the spore germination of F. culmorum. All cell-free cultures obtained from $P$. fluorescens I-4 restricted significantly the spore germination of $F$. culmorum with the maximum activity detected for supernatants obtained from the youngest culture. Cell-free culture from a 6-hour culture exhibits the statistically significant negative influence on conidia and the germination rate index amounted from 4.94 (at $O D=1.0$ ) to 3.51 (at $O D=2.0$ ) compared to the control 58.4 (Table 4).

Table 4. Influence the supernatants of Pseudomonas fluorescens I-4 on the spore germination of Fusarium culmorum

Tabela 4. Wpływ supernatantów Pseudomonas fluorescens I-4 na zdolność kiełkowania zarodników Fusarium culmorum

\begin{tabular}{lccccc}
\hline \multirow{2}{*}{$\begin{array}{c}\text { Density of culture } \\
\text { Gęstość hodowli }\end{array}$} & \multicolumn{5}{c}{$\begin{array}{c}\text { Culturig time } \\
\text { Czas hodowli }[\mathrm{h}]\end{array}$} \\
\cline { 2 - 6 } & $\begin{array}{c}\text { control } \\
\text { kontrola }\end{array}$ & 6 & 12 & 24 & 48 \\
\hline OD 1.0 & $59.35 \pm 1.75^{\mathrm{C}}$ & $4.94 \pm 1.63^{\mathrm{A}}$ & $5.04 \pm 1.05$ & $8.36 \pm 1.24$ & $10.52 \pm 0.96^{\mathrm{B}}$ \\
\hline OD 2.0 & $56.35 \pm 1.75^{\mathrm{C}}$ & $3.51 \pm 0.36^{\mathrm{A}}$ & $3.72 \pm 0.45$ & $5.21 \pm 1.22$ & $4.56 \pm 1.55^{\mathrm{B}}$ \\
\hline
\end{tabular}

OD - optical density - gęstość optyczna.

Germination inhibition of $F$. culmorum spores by a cell-free culture at optical density of $\mathrm{OD}=1.0$ of $P$. fluorescens $\mathrm{I}-4$ amounted to the values from $82.27 \%$ to $91.67 \%$. The highest effect was obtained for the higher density of bacterial culture. In these cases the degree of inhibition reached the level from $91.21 \%$ to $94.08 \%$ at OD $=2.0$. In both cases, the maximum inhibition of spore germination was achieved for the supernatants obtained from the 6-hour culture. As the age of the culture increased, the decrease of activity of $P$. fluorescens strain metabolites against to Fusarium spores was observed (Fig. 3).

The results of this study indicated that the Ps I-4 strain was able to significantly inhibit the growth of mycelium and spore germination of F. culmorum. Shalini 2008 reported that five $P$. fluorescens strains had a strong influence on spore germination of Fusarium sp. Moreover, it was observed that these strains demonstrated a greater activity when used in higher 
concentrations. They observed that the higher the concentration, the higher the percentage of spores inhibition (it amounted to the values from 22.7 to $100 \%$ ) thus exhibiting a concentration dependent activity.

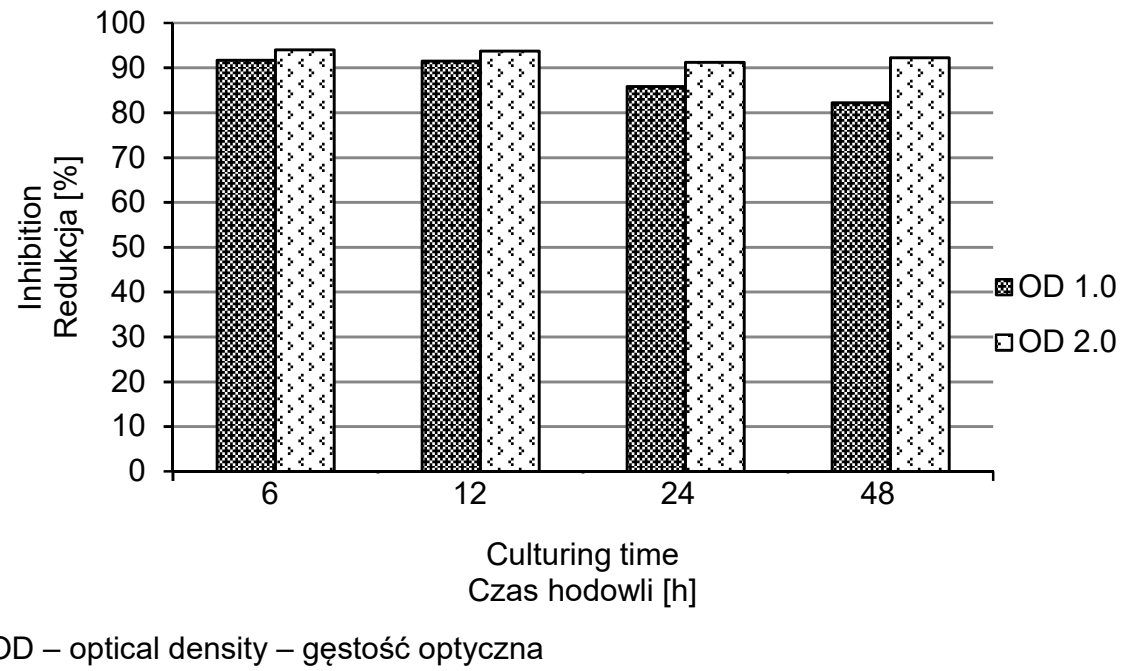

Fig. 3. Reduction of the spore germination of $F$. culmorum by Pseudomonas fluorescens I-4 Ryc. 3. Zahamowanie zdolności kiełkowania zarodników F. culmorum przez Pseudomonas fluorescens I-4

The results of this study indicated that the Ps I-4 strain was able to significantly inhibit the growth of mycelium and spore germination of F. culmorum. Shalini 2008 reported that five $P$. fluorescens strains had a strong influence on spore germination of Fusarium sp. Moreover, it was observed that these strains demonstrated a greater activity when used in higher concentrations. They observed that the higher the concentration, the higher the percentage of spores inhibition (it amounted to the values from 22.7 to 100\%) thus exhibiting a concentration dependent activity. There are various mechanisms involved in the biological control of phytopathogenic fungi by Pseudomonas spp. Numerous data in literature confirms the use of these microorganisms to control of pathogens, among others, Phytophtora sp., Pythium sp., Botrytis cinerea, Rhizoctonia solani, Fusarium spp. Selective activity of different strains of $P$. fluorescens against soil-borne phytopathogens has been described in many cases (Alemu and Alemu 2013; Koche et al. 2013; Mnif and Ghribi 2015; Grata 2016). This was explained by the ability of these bacteria to produce compounds that exhibit antagonistic activity against different fungi. These bacteria possess the ability to synthesize and secrete different active volatile and non-volatile compounds and mycolytic enzymes which are effectively active (chitinase, $\beta$-1,3-glukanase, protease, anticiotics, hydrogen cyanide, siderophores, lipases. In this study, the $P$. fluorescens I-4 was able to produce several metabolites. They demonstrated strong activity for protease, lipase and moderate activity for $\mathrm{HCN}$ production, cellulose secretion and solubilization of phosphours. The results of these studies are consistent with the reports of other authors who have observed the ability of Pseudomonas sp. to synthesize HCN, proteases and siderophores (Lejbølle 2004; Suresh et al. 2010; Jankiewicz 2010; Ramyasmruthi et al. 2012; Mnif and Ghribi 2015). 


\section{CONCLUSIONS}

In conclusion, several pathogenic Fusarium species occurred in the soil of asparagus plantation. Among them most numerous and dominated were two species, namely $F$. oxysporum and $F$. culmorum. In addition, the research showed that $P$. fluorescens I-4 strain exhibits a broad spectrum of antifungal activity on the mycelium growth and spore germination of $F$. culmorum. It was found that supernatants had about $20-40 \%$ stronger inhibitory effect on the spore germination of this fungus than on the linear growth. This strain is capable of producing bioactive metabolites, therefore it represents a potential biocontrol agent for the management of the Fusarium sp. However, it is necessary to carry out a field experiment to determine the effectiveness of $P$. fluorescens $1-4$ in the natural conditions.

\section{REFERENCES}

Alemu F., Alemu T. 2013. Antifungal activity of secondary metabolites of Pseudomonas fluorescens isolates as a biocontrol agent of chocolate spot disease (Botrytis fabae) of faba bean in Ethiopia. Afr. J. Microbiol. Res. 7(47), 5364-5373.

Andrzejak R. 2012. Assessment of occurrence of Fusarium spp. fungi on garden asparagus (Asparagus officinalis L.). Pytopathologia 64, 51-53.

Blok W.J., Bollen G.J. 1995. Fungi of roots and stem based of asparagus in the Netherlandes: species and pathogenicity. Eur. J. Plant Pathol. 101(1), 15-24.

Burgieł Z. 1984. Wpływ niektórych herbicydów na występowanie i rozwój patogenów powodujących choroby podsuszkowe pszenicy ozimej. Cz. II. Rozwój patogenów [Effect of some herbicides on the incidence and growth of pathogens causing wheat eyespot. Part II. Development of pathogens]. Acta Agr. Silv., Seria Agraria 23, 187-196. [in Polish]

Burgieł Z., Kończyk D. 1989. Reakcje grzyba Fusarium culmorum wyizolowanego z korzeni pszenicy ozimej na wybrane herbicydy [The reactions of the fungus Fusarium culmorum isolated from the roots of winter wheat to selected herbicides]. Acta Agr. Silv. 28, 25-31. [in Polish]

Cieślik E., Siembida A. 2011. Charakterystyka wartości odżywczej i właściwości prozdrowotnych szparaga lekarskiego Asparagus officinalis L.) [Nutritional value and pro-healthy properties of asparagus Asparagus Officinalis L. Post. Fitoter. 4, 275-281. [in Polish]

Dennis C., Webster J. 1971. Antagonistic properties of species-groups of Trichoderma. II. Production of volatile antibiotics. Trans. Br. Mycol. Soc. 57, 41-47.

Domsch K.H., Gams W. 1980. Anderson T.H. compendium of soil fungi. London, Academic Press. ISBN 0122204026.

Elmer W.H. 2015. Management of Fusarium crown and root rot of asparagus. Crop. Prot. 73, 2-6.

Elmer W.H. 2010. Asparagus in cennecticut and common diseases. The Connecticut Agricultural Experiment Station, www.ct.gov/caes, access: February 26, 2016.

Grata K. 2016. Biocontrol activities of Pseudomonas fluorescens against asparagus pathogen. Proc. ECOpole 10(1), 27-32.

Jankiewicz U. 2010. Bioaktywne metabolity ryzosferowych bakterii Pseudomonas [Bioactive metabolites of the rhizosphere Pseudomonas bacteria]. Woda Środ. Obsz. Wiej. 10(2), 83-92. [in Polish]

Jankiewicz U., Gołąb D., Frak M. 2013. Wpływ kwasu salicylowego syntetyzowanego przez bakterie Pseudomonas fluorescens i $P$. chlororaphis na fitopatogeniczne grzyby rodzaju Fusarium [Effect of salicylic acid, synthesized by the bacteria Pseudomonas fluorescens and $P$. chlororaphis on phytopathogenic fungi Fusarium]. Pol. J. Agron. 15, 65-68. [in Polish]

Kalomira E. 2007. Asparagus diseases. EJPSB 1(1), 76-83.

Koche M.D., Gade R.M., Deshmukh A.G. 2013. Antifungal activity of secondary metabolites produced by Pseudomonas fluorescens. The Bioscan. 8(2), 723-726. 
Koralewski Z., Waśkiewicz A., Irzykowska L., Bocianowki J., Kostecki M., Goliński P., Knaflewski M., Weber Z. 2011. Fungi presence and their mycotoxin distribution in asparagus spears. Pol. J. Environ. Stud. 20(4), 911-918.

Kumar R.S., Ayyadurai N., Pandiaraja P., Reddy A.V., Venkateswarlu Y., Prakash O., Sakthivel N. 2005. Characterization of antifungal metabolite produced by a new strain Pseudomonas aeruginosa PUPa3 that exhibits broad-spectrum antifungal activity and biofertilizing traits. J. Appl. Microbiol. 98, 145-154.

Lejbølle K.B. 2004. Molecular and ecological factors affecting survival and activities of the biocontrol agent Pseudomonas fluorescens CHA0, http://www2.dmu.dk/1_viden/2_Publikationer/3_Ovrige/ /rapporter/kbl_phd.pdf, access: February 3, 2017.

Leslie J.F., Summerell B.A. 2006. The Fusarium Laboratory Manual. USA, Blackwell Publishing. ISBN-13: 978-0-8138-1919-8.

Ligon J.M., Hill D.S., Hammer P.E., Torkewitz N.R., Hofmann D., Kempf H.J., Pe'e K.H. 2000. Natural products with antifungal activity from Pseudomonas biocontrol bacteria. Pest. Manag. Sci. 56, 688-695.

Łabanowski G., Nowak K., Sobolewski J. 2016. Poradnik sygnalizatora ochrony szparaga. Skierniewice, Inst. Ogrod. [in Polish]

Mahalakshimi S., Reetha D. 2009. Assessment of plant growth promoting activities of bacterial isolates from the rhizosphere of tomato (Lycopersicon esculentum L.). Rec. Res. Sci. Technol. 1(1), 026-029.

Maurya M.K., Singh R., Tomer A. 2014. In vitro evaluation of antagonistic activity of Pseudomonas fluorescens against fungal pathogen. J. Biopest. 7(1), 43-46.

Mnif I., Ghribi D. 2015. Potential of bacterial derived biopesticides in pest management. Crop. Prot. 77, 52-64.

Molinero-Ruiz L., Rubio-Perez E., Gonzalez-Domınguez E., Basallote-Ureba M.J. 2011. Alternative hosts for Fusarium spp. causing crown and root rot of asparagus in Spain. J. Phytopathol. 159, 114-116.

Nabrdalik M., Grata K. 2014. Antifungal activity of Pseudomonas fluorescens against phytopatogenic strains of Rhizoctonia solani. Proc. ECOpole 8(1), 65-69.

Nahiyan A.S.M., Robinson B.L., Jeffries P., Matsubara Y. 2011. PCR-SSCP analysis of Fusarium diversity in asparagus decline in Japan. Eur. J. Plant Pathol. 130, 197-203.

Pandey S.K., Chandel S.C.R. 2014. Efficacy of Pseudomonas as biocontrol agent against plant pathogenic fungi. Int. J. Curr. Microbiol. App. Sci. 3(11), 493-500.

Pitt J.I., Hocking A.D.1985. Fungi and food spoilage. London, Academic Press. ISBN 978-0-387-92207-2.

Ramyasmruthi S., Pallavi O., Pallavi S., Tilak K. Srividya S. 2012. Chitinolytic and secondary metabolite producing Pseudomonas fluorescens isolated from Solanaceae rhizosphere effective against broad spectrum fungal phytopathogens. Asian J. Plant Sci. Res. 2(1), 16-24.

Shalini R.S. 2008. Antifungal activity of Pseudomonas fluorescens against different plant pathogenic fungi. The Inter. J. Microbiol. 7(2), 1-7.

Suresh A., Pallavi P., Srinivas P., Kumar V.P., Chandra S.J., Reddy S.R. 2010. Plant growth promoting activities of fluorescent pseudomonads associated with some crop plants. Afr. J. Microbiol. Res. 4(14), 1491-1494.

Trojan P. 1992. Analiza struktury fauny [Analysis of fauna structure]. Memorab. Zool. 47, 124. ISBN 0076-6372. [in Polish]

Vanitha S., Ramjegathesh R. 2014. Bio control potential of Pseudomonas fluorescens against coleus root rot disease. J. Plant. Pathol. Microb. 5(1), 216.

Weber Z., Karolewski L., Irzykowaska L., Knaflewski M., Kosiada T. 2007. Occurrence of Fusarium species in spears of asparagus (Asparagus officinalis). Phytopathol. Pol. 45, 9-15.

Weber Z., Karolewski L., Irzykowska L., Knaflewski M., Kosiada T. 2007. Occurrence of Fusarium species in spears of asparagus (Asparagus officinalis). Phytopathol. Pol. 45, 9-15.

Weller D.M. 2007. Pseudomonas biocontrol agents of soliborne pathogens: Loocing back over 30 years. Phytopathology 97(2), 250-256. 
Abstract. Assessment of the effect of Pseudomonas fluorescens I-4 (Ps I-4) on the Fusarium culmorum isolated from the cultivation of white asparagus was the aim of the conducted research. Fusarium culmorum and other fungi were isolated on the PDA and asparagus media. Among the isolates obtained from soil, F. oxysporum and F. culmorum were the most dominant pathogens. The biological properties of non-volatile and volatile compounds of Ps I-4 were assessed with the culture-plate method on the PDA and Czapek media. The fungistatic activity of bacterium was determined against the growth rate index, the spore germination index and the rate of mycelial growth and spore inhibition. The results show differences in the fungistatic activity of $P$. fluorescens, dependent on the age and density of the bacterial culture, the type of medium and the presence of volatile or non-volatile metabolites. The obtained results prove, that Ps I-4 show a higher activity against the fungal spores germination (82-94\% inhibition) than on mycelium growth of $F$. culmorum. The highest inhibition of the linear growth of mycelium has been observed for the supernatants obtained from a 6-hour culture (64-76\% inhibition). $P$. fluorescens I-4 showed positive reactions for the production of $\mathrm{HCN}$, siderophores, protease, lipase and phosphate solubilisation. 
